\title{
Case analysis of the dispute of Bao Wan
}

\author{
Songqin $\mathrm{Ye}^{1, \mathrm{a}}$ Yang Chen ${ }^{1, \mathrm{~b}}$ \\ ${ }^{1}$ School of finance, Jiangxi Normal University, Nanchang city , Jiangxi Province 330022 \\ a148237897@qq.com b362802622@qq.com
}

Key words: Ownership, management right, corporate governance

\begin{abstract}
Bao Wan contest" is probably the most cited major event of the second half of the capital markets in 2015. From the initial treasure can silently holdings placards, Ampang low-key intervention, and Vanke former largest shareholder of Huarun group to silence, to sound tough against Bao Vanke management can acquire, as much as the year "Jun Wan dispute" Bao Wan dispute gradually into public view.
\end{abstract}

\section{Introduction}

"Bao million equity dispute" is essentially the problem of corporate governance, Vanke equity dispute is so noisy, that Chinese also lack of consensus on corporate governance. As everyone knows, to improve the quality of listed companies, mainly rely on the improvement of the corporate governance structure. Corporate governance is a scientific research enterprise is a power arrangement. Kind of company management and control system. It not only stipulate the responsibilities and rights of various participants in the company, and the corporation decision should follow the rules and procedures.

\section{Case backtracking}

2.1Company overview.Shenzhen Bao Investment Group Limited (hereinafter referred to as the Boland group) was founded in March 2000, the registered capital of 300 million yuan, is headquartered in Shenzhen, Yao Zhenhua is the only shareholder. Treasure to property development, including the group's finance, modern logistics, cultural tourism, five plate livelihood industry, under the jurisdiction of Baoneng real estate, Qianhai life, huge Shenghua, Guangdong cloud letter credit assessment, Guangdong microfinance, logistics industry, chuangbang group, Shenzhen Jianye, Shenzhen Bao Hui e-commerce, fresh agricultural products in Shenzhen. This involves a number of subsidiaries of the Bao Wan contest subsidiary is mainly Shenzhen jushenghua Limited by Share Ltd (hereinafter referred to as huge Shenghua) and before Sea life insurance Limited by Share Ltd (referred to as Qianhai life insurance)

Huge Shenghua was founded in 2002, by the Shenzhen Bao source Logistics Co. Ltd., Shenzhen City, Zhejiang Industrial treasure investment partnership (limited partnership), Shenzhen Bao chuangying investment enterprises (limited partnership) and Boland group and other four shareholders jointly, paid in capital of 16 billion 304 million yuan, of which the treasure group shares accounted for 67.4\%. Qianhai life was founded in February 2012, the registered capital of 8 billion 500 million yuan, accounting for 51\% of the shares of Ju Shenghua, headed by Yao Zhenhua.

Vanke Limited by Share Ltd was founded in 1984, in 1988 to enter the real estate, in 1991 as the Shenzhen Stock Exchange listed companies in second. After more than and 20 years of development, has become the largest residential development companies. Companies in the development process has selected "Forbes200 of the world's best small and medium-sized enterprises" and "top 200 Best Small Enterprises in Asia." the company has won the best "Investor Relations and other international authoritative media gave the best governance, investor relations and other awards, eight consecutive" Chinese most respected enterprise "title, established in the residential industry competitive advantage. In Vanke listed Later, Huarun group as the largest shareholder of Vanke, in the up to fifteen years of 
cooperation, not to participate in management, management led the development of the enterprise model, has been regarded as a model of corporate governance in the industry

2.2The process of the struggle for treasure.In January 2015, the treasure department's Qianhai life and its concerted action to start buying huge Shenghua Vanke stock, and by July 10th, the treasure Department holdings Vanke has reached 5\%, to July 24th, the treasure Department placards; read the placards, the shareholding ratio reached $10 \%$, in August 26 to date third placards, become Vanke the first major shareholders, the shareholding ratio reached $15.04 \%$. after four days on August 31st, Vanke former largest shareholder of Huarun group first positive coping Boland Department "hostile takeover" (Wang Shiyu), to 170000 shares, by September 1st, the share proportion reached $15.23 \%$, Vanke has become the largest shareholder 。On the other hand, treasure can continue to force, in November 24th and December 4th respectively and huge Shenghua Bao to 170000 shares, shareholding ratio increased to $20.008 \%$, the treasure can again become the largest shareholder of Huarun, and keep silent; December 10th, Bao can cost \$3 billion 700 million to buy 191 million shares of China Vanke, as of $11,22.45 \%$ shareholding, 1 shareholding advantage continued to increase. Along with the continued silence of the old club Huarun, Vanke management began to sound tough, 17 evening Wang Shi Vanke internal speech out, claiming that "no welcome Boland department to become the largest shareholder", refers to the treasure can not direct credit .18, the source of funds is not legitimate.18 morning treasure can be a low-key response to abide by the law, respect the rules, I believe the strength of the market in the afternoon to apply for suspension of Vanke Vanke, refused to treasure placards.

As of December 18, 2015 Vanke suspension, the shareholding ratio of treasure to Vanke reached 24.26\%, more than Huarun to become the largest shareholder of China Vanke, in the face of "the position of chairman." the crisis, Wang Shi claimed that confusion can treasure "savages", "credit is not enough, the tear forced war intensified.2016 years later in June 17th, the Wang Shi team to pull the Shenzhen City Metro Group shares of China Vanke, the goal is clear: to do the first major shareholder of Shenzhen Metro exclusive Po to at the same time, Huarun also is the first major shareholder status. A week later, the evening of June 23, 2016, Po can stand against million Buy Shenzhen Metro.Followed, behind Wang Shi 10 years of Huarun actually in its official platform. The treasure and treasure for the two companies Huarun voice before and after an hour apart. Suddenly, the media blew up, Wang Shi is more confused, Wang Shi 26, micro letter circle of friends who rely on trust, said: Huarun no cover open and the attacker to completely deny Vanke management, the fig leaf torn out.

\section{Problems behind the event}

3.1Through the battle of treasure, we see the fragility of China's stock market and the potential risk.Treasure can when the market close to 3000 points, the use of financial leverage, the presence of a large number of Vanke, Vanke to become the largest shareholder. Of course treasure can almost succeed, only the battle to save the treasure can control Vanke drama, caused an uproar in the media. The normal sense, mergers and acquisitions has been advocated the country, also support, is a good sign. But from the trend of the stock market bull market Vanke's back, and Wang Shi's performance does not seem optimistic. Nothing more than, "Bao Wan contest" again that the stock market is a market dominated by speculation. If people want to invest Vanke, the market is optimistic about the other enterprises. Industry should have such mergers and acquisitions

But don't forget to treasure, is stationed in the stock market, and its ability is the venture capital company, the market is the composition of the operation is too large. Vanke returns is recognized, after controlling for Vanke, future profits can continue to use, the use of leverage, to eat the other company. This is actually a vicious spiral, let us see the fragility of the stock market, the risk of operation has the potential.

3.2The interests of minority shareholders can not be guaranteed.Po million dispute is actually listed companies and major shareholders who fight, but their common feature is that the interests of minority shareholders, as the main focus of listed companies 
3.3Financial regulatory reform"Bao Wan contest" will be alerted three is expected but contrary to expectation what is hidden behind the financial regulatory reform demands. The issue of financial regulation after the "Bao Wan dispute has caused concerns of market participants. Insiders pointed out that in the current financial supervision under the background of funds once out of the bank, by the CBRC has actually been unable to achieve the effective use and flow supervision. According to the capital channel, treasure can reveal the clues, the final source of funding treasure to the system, but by the CBRC is difficult to achieve. It can treasure funds, the bank. The insurance and securities fund Gold and other areas, if there is no linkage between the three regulators, it is almost impossible to find out its source.

At present, Chinese implementation of the financial supervision system in the "information management" has been outdated, financial market machinery division, regulatory vacuum area and regulatory arbitrage phenomenon. In common. "Showing Bao Wan contest" to the picture, with the passage of the insurance funds of banks, securities, etc. switch back and forth, the traditional sense of the regulatory Division has no meaning.

3.4Supply side reform and the direction of the reform of the capital market provides a good inspiration.Provides a good enlightenment to the reform direction of the "Bao Wan contest" of the country is promoting the supply side structural reform and capital market, such as the reform of state-owned enterprises is how to change, how to protect the interests of investors, the equity structure of China Vanke A should be the most modern enterprise governance structure, because there is no actual controller, occupation managers can give full play to their professional talents and create maximum value for the company, at the same time, the independent director supervision, to realize the protection of investors is designed, and the independent director system is alienated, Vanke model obviously can be used for reference.

\section{Conclusion}

Capital is the right to speak.In the market, capital is right. Vanke market value of nearly three hundred billion yuan, treasure can spend 40 billion yuan to win the first major shareholder throne, its capital operation ability is impressive. This is not only related to or Vanke, but also reflect the new trends in the domestic market, the domestic financial capital operation is more and more mature now, those the ability to resist the weak or dispersed ownership of listed companies, may often have to face the fate of life was similar to alive in the future. In fact, more than a blind treasure shopping spree in the A stock market, if you do not want to be trampled upon the fate of many corporate entities and listed companies will be on the number of capital operation, the market value of the class.

Essential rule consciousness. The domestic capital market system is not perfect, the infirm, but even in such a game scene, which also have anyone to enter by the rules, let the capital in under the rules of love to kill. No matter what means treasure can seek to attack Vanke, must comply with the rules of the game. The day before, treasure can because as the obligation of information disclosure by the Shenzhen Stock Exchange issued a "money come from" choice.

Balance.In the modern corporate governance structure, the shareholders' meeting, board of directors, management and other efforts to balance each other is very important. The current Vanke Company growth is good, but I want to treasure map Tunxiang, or many people standing in Wang Shi side. However, if a company mismanagement, internal chaos, management has always to control the power, ignoring the interests of major shareholders, people will think that management is so strong it? In this regard, whether people can doubt the management of dog in the manger, against the interests of shareholders? So, judge Bao million disputes can not stop at the sight of not long term, check to see people and ignore the system. Vanke dispersed ownership, the first large shareholders weak public However, it is more and more strong, has its historical and realistic causes, but not necessarily in line with the modern corporate governance

\section{Acknowledgments}

The general program of the national social science fund the policy burden, financial transparency and preferential government resource allocation efficiency (16BGL047); Jiangxi Academy of social 
sciences plan project "government intervention, market reform and state-owned enterprise executives incentive" (14GL52)

\section{References}

[1]Andreou P C, Antoniou C, Horton J, et al. Corporate Governance and Firm - specific Stock Price Crashes[J]. European Financial Management, 2016, 22(5):916-956.

[2]Hong B, Li Z, Minor D. Corporate Governance and Executive Compensation for Corporate Social Responsibility[J]. Journal of Business Ethics, 2016, 136(1):199-213.

[3]Martin G, Farndale E, Paauwe J, et al. Corporate governance and strategic human resource management: Four archetypes and proposals for a new approach to corporate sustainability[J]. European Management Journal, 2016, 34(1):22-35.

[4]Lau C M, Lu Y, Liang Q. Corporate Social Responsibility in China: A Corporate Governance Approach[J]. Journal of Business Ethics, 2016, 136(1):73-87.

[5]Hopt K J. Corporate Governance of Banks and Other Financial Institutions after the Financial Crisis[J]. Ssrn Electronic Journal, 2015, volume 13(2):219-253(35).

[6]Davydov Y. Corporate governance and risk taking[J]. Dissertations \& Theses - Gradworks, 2015. 